\title{
How much space is given to women in local Kosovo newspapers competing for mayors?
}

\author{
Arbenita Sylejmani Nimani \\ $\mathrm{PhD}$ candidate, University of Tirana, Republic of Albania
}

\begin{abstract}
The purpose of this paper is to identify the space that was given in the local newspapers to women that competed for mayors during the election campaign held on November 3, 2013, in Kosovo, and to see if the newspapers can be one of the factors that in this election there were fewer women that competed and that only one was elected. On November 3, 2013, the local elections were held for 37 municipal mayors in Kosovo. From 37 municipalities there were 206 man and 8 women candidates. In all municipalities only one woman was elected as a mayor of municipality. We are waiting for the new local elections that will be held on October 2017, and again there will be fewer than $3 \%$ women who will compete. The methodology of this article is the content analysis. An analysis of the articles from three daily Kosovo newspapers was used, which are the most read, such as: Koha Ditore, Kosova Sot, and Zëri. The sample for the analysis included: the month of October, since on October 3rd the election campaign was officially started. In addition, it includes the first week and the last one of the month of October, 2013. From the analysis it is noticed that women who competed were given very little space in the newspapers. For example, the most widely read newspaper "Koha Ditore" during this period on the first page only mentioned 1 woman competing while men mentioned 42 times. With the very small number of women mentioned on the front page there is also the second most widely read newspaper in Kosovo, "Kosova Sot", which only once mentions a woman, while men are mentioned six times. The third most widely read newspaper, the "Zëri" newspaper, first page men mentioned 29 times while women 4 times. Considering the fact that patriarchal opinion prevails in Kosovar society, and when the newspapers do not give space to women who are competing, then it is conceivable that we have very few women to vote. Also, this tiny space given to women during the race implies that we have too few women competing because the biggest newspaper space would make women aware and stimulate them to compete, and of course we will have more women voted.
\end{abstract}

Keywords: spaces, newspapers, women, men, compete

\section{Introduction}

\section{The space that local newspapers in Kosovo give to women who run for mayors}

Before starting the interpretation of the results it is important to show why these three newspapers have been chosen for analysis. According to a survey conducted by Index-Kosovo in Kosovo in 2008, the most widely read newspapers in Kosovo are: Koha Ditore $36 \%$. The newspaper Kosova Sot follows with $35 \%$ and, Zeri's paper by $8 \%$.

The analysis shows that there is a big gender difference in how much space is given by Kosovo newspapers when women are competing. As can be seen from Figure 1 below, the most widely read newspaper in Kosovo "Koha Ditore", only one woman had mentioned on the first page during the election campaign. While, the men who competed were mentioned on the first page 42 times. Gender difference is also found inside the newspaper, where women were mentioned 11 times while men 52 times.

We also have the number 2 most read newspaper, which is the newspaper "Kosova Sot", which on the first page also mentioned only 1 woman, while the men this newspaper had mentioned 4 times in the front page. In this newspaper we have a huge gender difference in the newspaper, where 24 men and 6 women are mentioned.

The third newspaper listed in Kosovo, which is the newspaper "Zëri", also has a large gender difference on the front page. This newspaper distinguishes from the first two of the most widely read because there is the largest gender difference between men and women mentioned in this newspaper. On the front page of this newspaper 60 men have mentioned and 
only 4 women mentioned. Inside the newspaper the men politicians who ran were mentioned 287 times while competing women were mentioned 29 times.

\section{Figure 1: the space given women in newspaper who run for mayor}

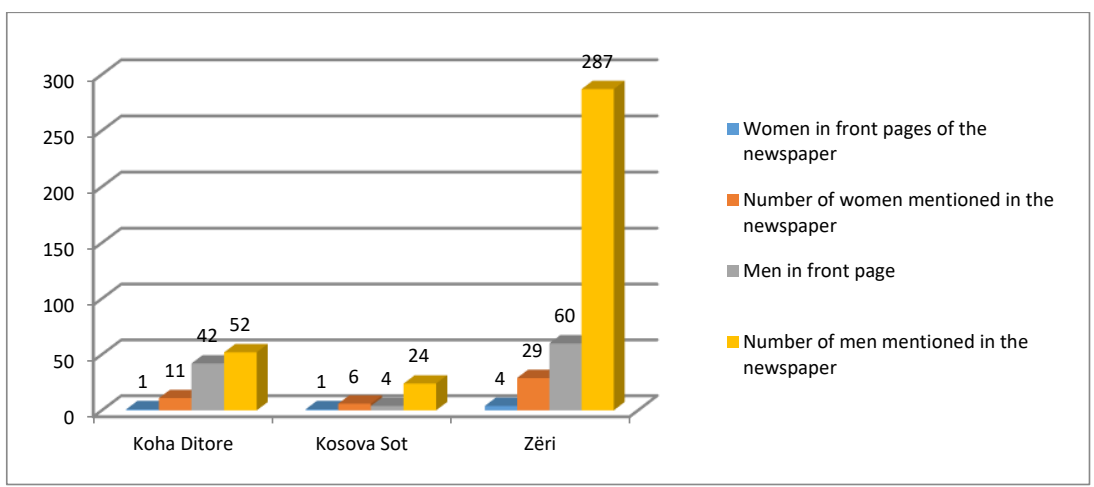

Source: National Library of Kosovo/respective newspapers

Media, with its own epithet as the fourth power, has an enormous role in people's lives, including the best opportunity to promote the issue of gender equality. Considering this role of the media, there should be harmony between gender issues and the media and journalism, because these two areas are inseparable. Therefore, it is very improbable to think that the media has no impact on people. (Gauntlett, 2008, p. 2 dhe 3)

The media not only has a reflection on public opinion, but it is also one of the socializing agents of the individual who has a great deal of influence on the formation of public opinion and the education of the people.

Media can have a huge impact on empowering women. Therefore, the Beijing Platform for Action was adopted at the Fourth Women's Conference in 1995. This platform identifies the issue of "women and the media" as one of the twelve critical and worrying areas, and emphasizes that "there is a possibility that the media contributes more to the advancement of women." This platform has also set two strategic objectives, where one of these objectives is dedicated to new media and new telecommunication technologies, through which they promote a balanced and unbiased stereotyped women in the media.

\section{Not only do the newspapers have gender differences}

The small number of women is not just of those who run for mayors. Also, newspapers do not remain the only ones that have large gender differences. In order to have a clear situation, it is important to have a gender overview of the current 2017 outgoing Government.

For example from 19 ministries -14 men are ministers and only 5 women are ministers. On the position of deputy ministers there are 20 men and only 4 women, see fig. Nr. 2. Even though every political party in Kosovo has $30 \%$ of women, as it is required by legal quota, still these $30 \%$ of women remain invisible in decision-making positions. 


\section{Figure 2: Gender structure in Kosovo government 2017}

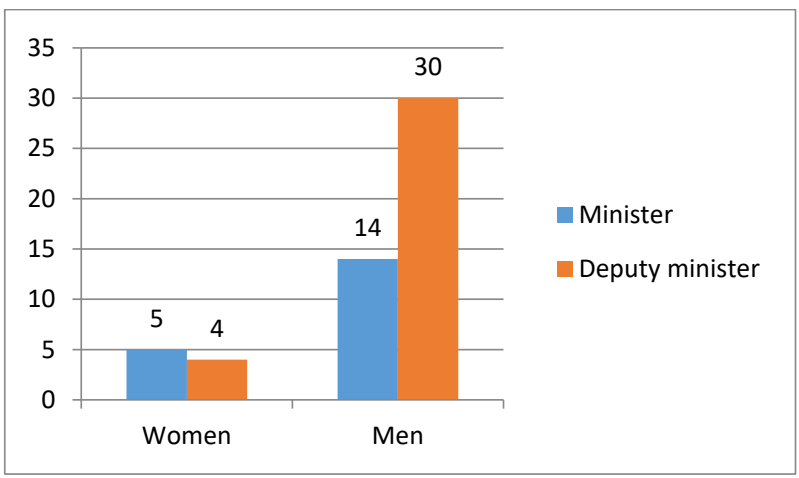

Source: Kosovo Government: https://www.rks-gov.net/sq-AL/Pages/Fillimi.aspx

This tells us how much patriarchal mindset still prevails in Kosovo society. For many centuries, this mentality was not installed in the Kosovar mentality. Therefore, the Albanian sociologist Zyhdi Dervishi was right in claiming that in Albanian mythology, the portrait of the Albanian woman was compared to the image of Zana (fairy), who was believed to be a woman dressed in bridal clothes, but also distinguished by her bravery. But the Ottoman Empire was the one that put the idea that military functions and war were men's occupations and jobs. Prejudices for women have overwhelmed the entire atmosphere of Albanian society and as an invisible gelatinous mass prevented the engagement of girls and women in political life. (Dervishi, 2011, p. 18).

\section{Why so few women voted?}

It can be quite rightly pointed out that the newspaper can be considered one of the reasons why we have very few women voted in Kosovo, and also why very few women compete for mayors.

On the other side, it is not only the media, in these case newspapers, the only factor that determines why we have so few women voted. An important role has also the political culture that we have in Kosovo. Here, political culture that prevails is that we do not see the candidates and do not read the programs of the political parties. In Kosovo, voting for political party is done based on emotional bonds to the party, without reading the program or seeing the candidate. Political entities in Kosovo are viewed on the basis of territories and in each area so far are known the result in advance of who will win the elections.

\section{Why are media and politics very close?}

At the time when these 8 women competed for mayors, in Kosovo we had a woman as the country president. It is not the purpose of this paper nor has the analysis devoted to the criticisms for her. But considering it very important to mention that there was much criticism at the time, both for her appearance and performance. Although there is no empirical and scientific evidence in Kosovo regarding what political party owns any kind of media, there are some small articulations not scientific but individual, which are told by the people on which media belongs to which political party. But, from what we see during the political campaign, there are several media outlets that speak in favor of one or another political party in Kosovo. What can we say in this case? That if Mrs. Jahjaga had a media platform there wouldn't be mainly criticism addressed to her, but a new reality would be presented towards Mrs. Jahjaga, different from the one we are used to see on most of the occasions

Or what can we say about these 8 women competing for mayoral elections in these elections if they had a newspaper, would they give themselves more space? Of course yes. They would give themselves more space, and surely today we would have more women as mayors, and today, more than $3 \%$ of women would compete for mayor. It would also be considered a very powerful tool to overcome prejudices about women in politics.

The very fact that the history of newspaper creation has started with the political developments of societies, even the first publications have begun in the form of bilboards, policy pamphlet publications or other interest groups in general (Berisha, 
2007 , p. 44), shows why politics has a very close relationship with the media and in this case newspapers. Because of this very close relationship between media and politics, where the media itself has the power to change reality depending on social and political situations or interests, naturally the question arises as to how we can have a realistic picture of women's portrayal in the media, and in this case, in newspapers? Or, as Giovanni Sartori said that in the case of media monopoly there is no worthy public opinion (Sartori, 1998).

Experts in the field of mass communication argue that political competition is deeply transformed with the development of political marketing based on lure, speed, restricted vocabulary, and the media is taken as a convenience and short way to communicate with citizens (Maigret, 2010).

German politician Werner Patzelt has found a kind of interdependence between government officials and journalists in his research, pointing out that the relationship between them is multifaceted because each one is dependent on the other (Patzelt J., 2016).

The democratic country should be followed by the free and independent media, as Monro E.Prajs and Peter Krug said, in their study "The Environment Friendly for Free and Independent Media", saying that without the press free democracy is impossible, as the courts claim (2000).

\section{Conclusion}

Newspapers in Kosovo do not offer minimal space for women politicians who run for mayors, compared to their male counterparts. Normally, having this situation in newspapers, how can we expect to have more women voted?

The media, in this case newspapers, as one of the important pillars of democracy, and the educational role it has, should work in the spirit of non-discriminatory gender-based reporting. This is to make the newspapers give much more space for political women when they run for mayors. It remains to be hoped that the situation will improve as soon as the election campaign for elections to be held in October of this year (2017) is opened.

\section{Bibliography}

[1] Berisha, I. (2007). Media agjensët e komunikimeve. Prishtinë: Universiteti AAB.

[2] Dervishi, Z. (2011). Gratë në Turbulencat e Mendësive dhe Realiteti Politik. Tiranë: Emal.

[3] Gauntlett, D. (2008). Media, Gender and Identity - An Introduction (2 ed.). London: Routledge.

[4] Maigret, E. (2010). Sociologjia e Komunikimit dhe e Mediave. Tiranë: Papirus.

[5] Patzelt J., W. (2016). comparative political analysis; comparative legislatures; political communications. Retrieved October 12, 2016, from ETC.PP-Patzelts Politik: http://wjpatzelt.de/

[6] Sartori, G. (1998). Ç'është demokracia? Tiranë: Dituria. 